\title{
Commentary: Reducing Viability Bias in Analysis of Gut Microbiota in Preterm Infants at Risk of NEC and Sepsis
}

\author{
Gemma Agustí ${ }^{1}$ and Francesc Codony ${ }^{2 *}$ \\ ' Departament d'Òptica i Optometria, Universitat Politècnica de Catalunya-Barcelona Tech, Terrassa, Spain, ${ }^{2}$ Laboratori \\ Municipal - Aigües de Mataró, Mataró, Spain
}

Keywords: viability PCR, live-dead distinction, analysis bias, microbiome, PMA

\section{A commentary on}

Reducing Viability Bias in Analysis of Gut Microbiota in Preterm Infants at Risk of NEC and Sepsis

by Young, G. R., Smith, D. L., Embleton, N. D., Berrington, J. E., Schwalbe, E. C., Cummings, S. P., et al. (2017). Front. Cell. Infect. Microbiol. 7:237. doi: 10.3389/fcimb.2017.00237

\section{OPEN ACCESS}

Edited by:

Pascale Alard,

University of Louisville, United States

Reviewed by:

Morgan Langille,

Dalhousie University, Canada

*Correspondence:

Francesc Codony

francesc.codony@aiguesmataro.cat

Received: 22 June 2017

Accepted: 05 June 2018

Published: 20 June 2018

Citation:

Agustí G and Codony F (2018)

Commentary: Reducing Viability Bias in Analysis of Gut Microbiota in

Preterm Infants at Risk of NEC and

Sepsis.

Front. Cell. Infect. Microbiol. 8:212.

doi: 10.3389/fcimb.2018.00212
The recent work by Young et al. (2017) demonstrates the importance of obtaining accurate data when analyzing the microbial community in real-life complex samples. These authors showed that an analysis of gut microbiota samples from preterm infants who at risk of necrotizing enterocolitis (NEC) and sepsis could be biased if the analysis includes DNA from dead cells. The study used a viability PCR (vPCR) approach to overcome this obstacle. Notably, vPCR uses specific photoreactive dye that cannot cross intact cell membranes. When a sample is incubated with this dye and exposed to light, the dye irreversibly binds to DNA in dead cells that have damaged cell membranes. This step effectively neutralizes the DNA and prevents it from being detected by PCR.

Regarding the importance of removing DNA from dead cells during microbial analysis, similar conclusions have been drawn by studies of, for example, environmental samples (Carini et al., 2016) and clinical specimens (Rogers et al., 2013). We agree with this premise and encourage others to use vPCR in microbial analysis, but caution that proper sample preparation is required for this technique.

vPCR methodology is theoretically simple to use since it requires only a reagent and a light source; however, as with many techniques, a lack of practical experience with the technique led the authors to overlook some important considerations. vPCR is still relatively new, with the first paper by Nogva et al. (2003). The scientific community has developed strategies and general rules for optimizing the vPCR workflow; some of these strategies were reviewed by Fittipaldi et al. (2012). More recent work has demonstrated that during sample manipulation, plastic can contribute to false positive results. Indeed, the walls of microtubes can retain free DNA, thereby preventing the nucleic acid from interacting with the reagent. Accordingly, the DNA fraction on the walls of the microtubes is not neutralized, and when it is detected, it is incorrectly assigned to the live DNA fraction (Agustí et al., 2017). This is only one example of how technical issues during early sample treatment steps can affect the conclusions of the analysis. For this reason, it is our opinion that despite the valuable conclusions, some microbiome analyses based on vPCR have hidden weaknesses.

In the paper by Young et al. (2017), the authors analyzed stool samples that were suspended in PBS, but the $\mathrm{pH}$ and the oxygen levels of standard PBS solutions were not optimal for 
ensuring the viability of the cells in the stool samples. Therefore, the sample handling steps themselves could have affected the viability of some cells in the specimen. For example, only half of the anaerobic microorganisms from the mammalian large bowel survive exposure to $\mathrm{O}_{2}$ for $5 \mathrm{~min}$, and this percentage decreases to $3-5 \%$ after $20 \mathrm{~min}$ of exposure (Brusa et al., 1989). This effect is quite predictable and easy to understand; however, other important aspects, such as centrifugation (Peterson et al., 2012), the time between sample collection and storage (Cuthbertson et al., 2014), and freeze/thawing (Cuthbertson, 2015) can also lead to bias in culture-independent analysis.

The authors evaluated the effect of freezing the samples and concluded that freeze/thawing did not change the results for the stool samples. However, factors other than storage were not

\section{REFERENCES}

Agustí, G., Fittipaldi, M., and Codony, F. (2017). False-positive viability PCR results: an association with microtubes. Curr. Microbiol. 74, 377-380. doi: 10.1007/s00284-016-1189-3

Brusa, T., Canzi, E., Pacini, N., Zanchi, R., and Ferrari, A. (1989). Oxygen tolerance of anaerobic bacteria isolated from human feces. Curr. Microbiol. 19, 39. doi: $10.1007 / \mathrm{BF} 01568901$

Carini, P., Marsden, P. J., Leff, J. W., Morgan, E. E., Strickland, M. S., and Fierer, N. (2016). Relic DNA is abundant in soil and obscures estimates of soil microbial diversity. Nat. Microbiol. 19:16242. doi: 10.1038/nmicrobiol.2016.242

Cuthbertson, L., Rogers, G. B., Walker, A. W., Oliver, A., Hafiz, T., Hoffman, L. R., et al. (2014). Time between collection and storage significantly influences bacterial sequence composition in sputum samples from cystic fibrosis respiratory infections. J. Clin. Microbiol. 52, 3011-3016. doi: 10.1128/JCM.00764-14

Cuthbertson, L., Rogers, G. B., Walker, A. W., Oliver, A., Hoffman, L. R., Carroll, M. P., et al., (2015). Implications of multiple freeze-thawing on respiratory samples for culture-independent analyses. J. Cyst. Fibros. 14, 464-467. doi: 10.1016/j.jcf.2014.10.004

Fittipaldi, M., Nocker, A., and Codony, F. (2012). Progress in understanding preferential detection of live cells using viability dyes in combination with DNA amplification. J. Microbiol. Methods. 91, 276-289. doi: 10.1016/j.mimet.2012.08.007 considered, so it remains unclear whether their conclusions were influenced by additional biases.

The work of Young et al. is valuable, and the conclusions very clearly show the importance of overcoming bias due to DNA from dead cells in a microbial diversity analysis. We suggest that an additional warning about the importance of appropriate sample handling would be helpful to readers who may wish to conduct similar analyses.

\section{AUTHOR CONTRIBUTIONS}

Both authors reviewed the original work and wrote this commentary.

Nogva, H. K., Drømtorp, S. M., Nissen, H., and Rudi, K. (2003). Ethidium monoazide for DNA based differentiation of viable and dead bacteria by 5'-nuclease PCR. Biotechniques 34, 812-813.

Peterson, B. W., Sharma, P. K., van der Mei, H. C., and Busscher, H. J. (2012). Bacterial cell surface damage due to centrifugal compaction. Appl. Environ. Microbiol. 78, 120-125. doi: 10.1128/AEM.06780-11

Rogers, G. B., Cuthbertson, L., Hoffman, L. R., Wing, P. A., Pope, C., Hooftman, D. A., et al. (2013). Reducing bias in bacterial community analysis of lower respiratory infections. ISME J. 7, 697-706. doi: 10.1038/ismej.2012.145

Young, G. R., Smith, D. L., Embleton, N. D., Berrington, J. E, Schwalbe, E. C, Cummings, S. P. et al. (2017). Reducing Viability Bias in Analysis of Gut Microbiota in Preterm Infants at Risk of NEC and Sepsis. Front. Cell. Infect. Microbiol. 7:237. doi: 10.3389/fcimb.2017.00237

Conflict of Interest Statement: The authors declare that the research was conducted in the absence of any commercial or financial relationships that could be construed as a potential conflict of interest.

Copyright (C) 2018 Agustí and Codony. This is an open-access article distributed under the terms of the Creative Commons Attribution License (CC BY). The use, distribution or reproduction in other forums is permitted, provided the original author(s) and the copyright owner are credited and that the original publication in this journal is cited, in accordance with accepted academic practice. No use, distribution or reproduction is permitted which does not comply with these terms. 